\title{
BENDING STRENGTH OF LIGNOCELLULOSIC MATERIALS IN SOFTENING CONDITION*
}

\author{
Wahyu Dwianto ${ }^{1 * *}$, Ratih Damayanti ${ }^{2}$, Teguh Darmawan ${ }^{1}$, Prabu Satria Sejati ${ }^{1}$, Fazhar Akbar ${ }^{1}$, \\ Danang Sudarwoko Adi ${ }^{1}$, Adik Bahanawan ${ }^{1}$, Yusup Amin ${ }^{1}$, and Dimas Triwibowo ${ }^{1}$ \\ ${ }^{1}$ Research Center for Biomaterials, Indonesian Institute of Sciences, \\ Jl. Raya Bogor Km. 46, Bogor 16911, West Java, Indonesia \\ ${ }^{2}$ Forest Product Research and Development Center, Ministry of Environment and Forestry, \\ Jl. Gunung Batu No.5 Bogor 16610, West Java, Indonesia
}

Received: 27 March 2020, Revised: 25 April 2020, Accepted: 26 April 2020

\begin{abstract}
BENDING STRENGTH OF LIGNOCELLULOSIC MATERIALS IN SOFTENING CONDITION. Manually rattan and bamboo are more easily bent than wood. A further question, whether these are due to the softening behaviour of chemical components or their anatomical structures. This research is aiming to understand the softening behaviour and viscoelastic property of wood, rattan and bamboo as lignocellulosic materials. Nine years-old fast-growing teak wood (Tectona grandis L.f.), rattan (Calamus sp.), and three-yearsold andong bamboo (Gigantochloa pseudoarundinaceae (Steud.) Widjaja) were used for the experiments. Wood and rattan samples were taken from the bottom, middle and upper parts. Bamboo samples were cut from the $1^{\text {st }}$ to $20^{\text {th }}$ internodes. Static bending tests were carried out in fresh (green) as control samples, air-dried, and softened by microwave heating (MW) for 1 minute to determine the modulus of rupture (MOR) and modulus of elasticity (MOE). The results showed that the MOR and MOE values of wood, rattan, and bamboo increased from fresh to air-dried condition, and decreased by MW. When compared at the same density, a drastic increase was observed for the normalized MOR value in air-dried rattan, i.e. 2.5 fold. However, the decreasing of all the normalized MOR values were almost the same, i.e. 0.5 fold when MW softened them. The improvement also appeared for the normalized MOE value in air-dried rattan, i.e. 3 fold and decreased to almost zero by MW. These results indicated that rattan was more easily bent, followed by bamboo and then wood. Hydrothermal properties of chemical components significantly affected the changes of strength (MOR) and elastic properties (MOE). However, the differences in bending strength of wood, rattan, and bamboo were more likely due to differences in their anatomical structures.
\end{abstract}

Keywords: Bending strength, lignocellulosic materials, softening condition, anatomical structures

KEKUATAN LENTUR DARI BAHAN BERLIGNOSELULOSA PADA KONDISI PELUNAKAN. Rotan dan bambu lebih mudah dilengkungkan daripada kayu secara manual. Pertanyaan selanjutnya, apakah hal ini disebabkan oleh perilaku pelunakan komponen kimia atau struktur anatominya. Oleb karena itu, penelitian ini bertujuan untuk memahami perilaku pelunakan dan sifat viskoelastik. kayu, rotan, dan bambu yang merupakan bahan berlignoselulosa. Material yang digunakan dalam percobaan adalah sampel kayu jati (Tectona grandis L.f.) cepat tumbuh berumur 9 tahun, rotan (Calamus sp.), dan bambu andong berumur 3 tabun (Gigantochloa pseudoarundinaceae (Steud.) Widjaja). Sampel diambil dari bagian bawah, tengah dan atas untuk kayu dan rotan, sedangkan untuk bambu dipotong dari ruas ke-1 sampai ke-20. Pengujian lentur statis dilakukan pada kondisi segar sebagai kontrol, kering udara, dan dilunakekan dengan pemanasan gelombang mikro (MW) selama satu menit untuk menentukan modulus patah (MOR) dan modulus elastisitas (MOE). Hasil penelitian menunjukkan bahwa nilai MOR dan MOE kayu, rotan, dan bambu meningkat dari kondisi segar ke kering udara, dan menurun dengan MW. Jika dibandingkan dengan kerapatan yang sama, terjadi peningkatan drastis dari nilai normalisasi MOR rotan pada kondisi kering udara, yaitu 2,5 kali lipat. Namun, penurunan nilai normalisasi MOR selurubnya hampir sama, yaitu 0,5 kali lipat ketika dilunakean dengan MW. Peningkatan luar biasa juga terjadi pada nilai normalisasi MOE rotan pada kondisi kering udara, yaitu 3 kali lipat dan menurun hampir nol dengan MW. Hasil ini menunjukean bahwa rotan lebih mudah dilengkungkan, diikeuti oleh bambu, kemudian kayu.

\footnotetext{
*This study has been presented in the General Assembly and the $3^{\text {rd }}$ International Symposium of JSPS Alumni Association of Indonesia (ISJAAI-3) "The Role of JAAI to Promote Food, Water, Energy, Human, and Environmental Security", held on 31 October 2019 at Hotel Salak The Heritage, Bogor, West Java, Indonesia.

*Corresponding author: wahyudwianto@yahoo.com
} 
Sifat hidrotermal komponen kimia secara signifikan mempengarubi perubahan kekuatan (MOR) dan sifat elastis (MOE). Namun, perbedaan dari kekuatan lentur kayu, rotan, dan bambu tersebut lebih disebabkan oleh perbedaan struktur anatominya.

Kata kunci: Kekuatan lentur, bahan berlignoselulosa, kondisi pelunakan, struktur anatomi

\section{INTRODUCTION}

Curved wooden, bamboo, and rattan products are generally applied to furniture products, as well as to residential building components (door frames/windows), musical and sports instruments, toys, and other necessities. The conventional method of obtaining curved wooden products is done by cutting the wooden beams into a bent wood and connecting them to get the expected curve shape. Based on the process, this conventional method is easy to work because it only uses simple wooden techniques and tools. However, the deficiency and disadvantage of this traditional woodworking process is the wasting of wood raw materials, decreasing the wood strength due to fibre cutting, and reducing the beauty of wood fibre direction (Dwianto et al., 2019).

Bending straight solid wood is one possible solution in creating curvature shaped wood. Bending solid wood requires specific equipment and technique so that it needs basic knowledge of wood bending procedures. The wood bending mechanism is almost the same as a radial compression of wood (Dwianto, Inoue, \& Norimoto, 1997). However, the length of the outer part of the curve must not change because it cannot receive tension forces to some extent so that the compression forces occur in the inner part longitudinally and radially. Therefore, the possibility is that it can be overcome by softening, deforming, as well as setting processes. Softening can be achieved by heating the wood in fresh, wet, high moisture content or water-saturated conditions (Hamdan, Dwianto, Morooka, \& Norimoto, 2000; 2004). Deforming may be possible when the wood is in the softening phase. The setting is a drying process when the wood is in a deformed state to get the drying set.

Wood, rattan, and bamboo are lignocellulosic materials which consists of nature cellulose, hemicellulose, and lignin (Chen, 2015), and a mixture of natural polymers (Dotan, 2014) . The three main cell wall components contribute differently to the strength properties of the lignocellulosic materials. Hemicellulose is the bonding agent or cross-linking material between cellulose and lignin. Cellulose acts as reinforcement that provides tension forces and lignin for compression forces (Lum, Lee, Ahmad, Halip, \& Chin, 2019). On the other hand, properties of lignocellulosic materials also depend on the anatomical structures and some other parameters (Asim, Saba, Jawaid, \& Nasir, 2018). The chemical composition of cellulose, hemicelluloses, and lignin varies from one plant species to another, and even in different parts of the same plant (Li et al., 2014). Wood is a heterogeneous, hygroscopic, cellular, and anisotropic material. It consists of cells, and the cell walls are composed of microfibrils of cellulose (40-50\%), hemicellulose $(15-25 \%)$, and lignin (15-30\%). Aside from the lignocellulose, wood consists of a variety of low molecular weight organic compounds, called extractives (Agneta, Kuckurek, Pyiatte, \& EE, 1993). Rattan is composed of thick walled, heavily lignified parenchyma cells and vascular bundles (Weiner \& Liese, 1998). Generally, rattan stem consists of holocellulose (71-76\%), cellulose (39-58\%), lignin (18-27\%), and starch (18-23\%) (Zuraida, Maisarah, \& Maisarah, 2017). The cellulose and lignin contents correlate significantly with rattan strength. Higher cellulose content increases the modulus of rupture (MOR) of the rattan. Higher lignin 
content provides stronger bonds between rattan fibres. Physical (fresh and air-dry water contents, shrinkage and density) and mechanical properties (bending strength) are also taken into account when considering the utilization of rattan, particularly for large-diameter rattan (Olorunnisola \& Adefisan, 2001). The three major chemical components of bamboo, which are cellulose, hemicelluloses and lignin, are closely associated in a complex structure (Khalil et al., 2012). Those three components are about $90 \%$ of the total bamboo mass, while the minor parts are pigments, tannins, protein, fat, pectin, and ash. Others include resins, waxes and inorganic salts. These constituents play an essential role in the physiological activity of bamboo and are found in the cell cavity. The chemical compositions of bamboo are known to be similar to that of wood, mainly consists of cellulose $( \pm 55 \%)$, hemicellulose and pentosan $( \pm 20 \%)$, and lignin $( \pm 25 \%)(\mathrm{Li}$, Wang, Wang, Cheng, \& Han, 2010). Still, bamboo has a higher content of minor components compared to wood (Fazita et al., 2016). The composition varies based on years of growth, season, species, and the part of the culm.

Bend-ability of the wood or other lignocellulosic materials depends on their softening behaviour and viscoelastic property. The softening temperature of wood saturated with water has been reported by Becker \& Noack (1968) to be between $80^{\circ} \mathrm{C}$ and $90^{\circ} \mathrm{C}$ in agreement with the glass transition temperatures for saturated modified lignin measured by Goring (1963). Lignin content of wood, rattan, and bamboo is in the range of $15-30 \%$ (Li et al., 2014), 18-27\% (Zuraida, Maisarah, \& Maisarah, 2017), and $\pm 25 \%$ (Li, Wang, Wang, Cheng, \& Han, 2010), respectively. Therefore, they can be softened at almost the same temperature. Viscoelasticity is a property of materials that exhibits both viscous and elastic characteristics when they are undergoing deformation (Meyers \& Chawla, 2008). Viscous materials resist shear flow and strain linearly with time when a stress is applied. Elastic materials strain when stretched, and immediately return to their original state once the pressure is removed. Viscoelastic materials have elements of both of these properties and thus exhibit time-dependent strain. Whereas elasticity is usually the result of bond stretching along crystallographic planes in an ordered solid, viscosity is the result of the diffusion of atoms or molecules inside an amorphous material.

This research aimed to understand the softening behaviour and viscoelastic property of wood, rattan, and bamboo as lignocellulosic materials. The purpose was to observe why rattan and bamboo are more easily bent than wood, whether these are due to the softening behaviour of the chemical components or their anatomical structures. Static bending tests of wood, rattan, and bamboo were carried out in fresh, air-dried, and softened conditions by microwave heating to answer this question. Furthermore, the bending strength of wood, rattan, and bamboo was comparable, and a light microscope observed their anatomical structures.

\section{MATERIAL AND METHOD}

\section{A. Samples Preparation}

Nine years-old fast-growing teak wood (Tectona grandis L.f.), rattan (Calamus sp.), and 3 years-old andong bamboo (Gigantochloa pseudoarundinaceae (Steud.) Widjaja) were used for the experiments. Average diameter at breast height of teak tree and rattan stem was $40 \mathrm{~cm}$ and $3 \mathrm{~cm}$, respectively. On the other hand, outer part diameter of the bamboo culm was $9 \mathrm{~cm}$ in the bottom and $7 \mathrm{~cm}$ in the upper part. Wood and rattan samples were cut $30 \mathrm{~cm}$ from the bottom, middle and the upper parts. Bamboo samples were taken from the $1^{\text {st }}$ to $20^{\text {th }}$ internodes.

Moisture content (MC) and air-dried density (e) of the samples were measured from a sample size of $2 \mathrm{~cm}$ ( length) x $2 \mathrm{~cm}$ ( width) x $1 \mathrm{~cm}$ (thickness). Static bending tests were conducted from a sample size of $28 \mathrm{~cm}$ (length) x $2 \mathrm{~cm}$ (width) x $1 \mathrm{~cm}$ (thickness) to determine modulus of rupture (MOR) and modulus of 
elasticity (MOE) according to British Standard (1957). Especially the thickness of bamboo samples depended on their internodes along the culms.

\section{B. Measurements of Physical and Mechanical Properties}

Moisture content (MC) of the samples were measured by formula $\mathrm{MC}(\%)=[($ fresh weight - oven-dried weight/oven-dried weight) x 100\%], and $\varrho$ were obtained from $\varrho\left(\mathrm{g} / \mathrm{cm}^{3}\right)=$ [air-dried weight/air-dried volume].

Static bending tests were carried out in fresh (as control samples), air-dried, and softened by microwave heating. Microwave heated the fresh samples for one minute, which was wrapped by heat-resistant plastic to soften the samples. The average temperature inside the microwave was $120^{\circ} \mathrm{C}$. The MOR and MOE values were calculated using the formula MOR $\left(\mathrm{kg} / \mathrm{cm}^{2}\right)=$ $\left[(3 P L) /\left(2 b b^{2}\right)\right]$, and MOE $\left(\mathrm{kg} / \mathrm{cm}^{2}\right)=\left[\left(\Delta P L^{3}\right) /\right.$ $\left.\left(4 \Delta \mathrm{y} b h^{3}\right)\right]$, where $P=$ load $(\mathrm{kg}), \Delta P=$ load difference $(\mathrm{kg}), L=\operatorname{span}(\mathrm{cm}), \Delta y=$ deflection (cm), $b=$ sample width $(\mathrm{cm})$, and $h=$ sample thickness $(\mathrm{cm})$. For bamboo samples, loading direction was conducted in the inner part with adjustment span (L) according to their thickness. All the measurements were carried out with three replications. The normalized values of MOR and MOE were calculated from MOR and MOE values of air-dried or softened conditions divided by that of fresh conditions in the same $Q$.

\section{Anatomical Structure Observations}

The transversal section of the samples was cut by a sliding microtome to a thickness of 20 $\mu \mathrm{m}$ then dehydrated with $30 \%, 50 \%, 70 \%$, and $96 \%$ alcohol, carboxyl, and toluene, respectively. The sectioned transverse surface then was mounted with entellan (Dwianto et al., 2019) The images of each section were captured with a light microscope (Olympus BX-51) equipped with a digital camera (Olympus DP 73).

\section{RESULTS AND DISCUSSION}

\section{A. Result}

Figure 1 shows moisture content (MC) of fresh wood, rattan, and bamboo. MC of middle parts for both wood and rattan was higher than of the bottom and upper parts. However, their average MC was extremely different, i.e. $103.16 \%$ and $211.42 \%$, compared to bamboo respectively. On the other hand, it naturally decreased from $54.35 \%$ in the bottom ( $1^{\text {st }}$ internode) to $37.75 \%$ in the upper parts $\left(20^{\text {th }}\right.$ internode) for bamboo.

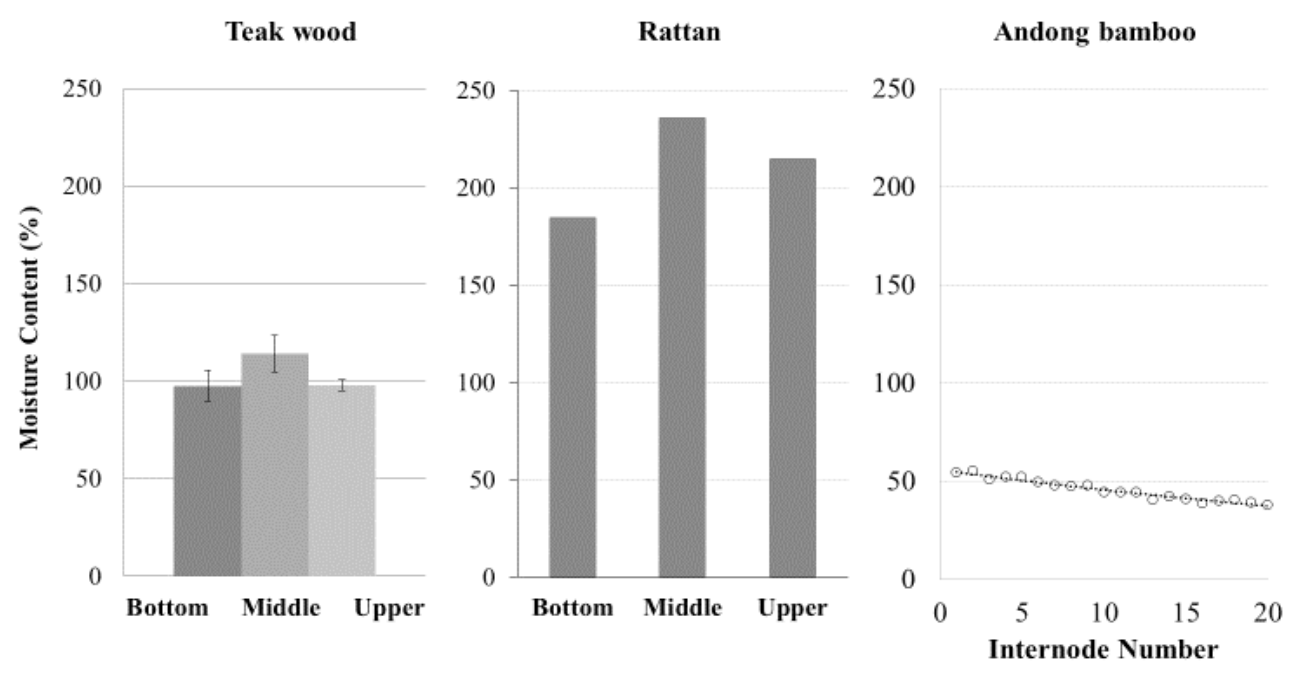

Figure 1. The moisture content of fresh wood, rattan, and bamboo 
Figure 2 shows air-dried density ( $\varrho$ ) of wood, rattan, and bamboo, in equilibrium moisture content (EMC). The $\varrho$ varied in the bottom, middle, and upper parts for wood and rattan samples. The average $\varrho$ of wood was slightly higher $\left(0.55 \mathrm{~g} / \mathrm{cm}^{3}\right)$ than that of rattan $(0.48 \mathrm{~g} /$ $\left.\mathrm{cm}^{3}\right)$. However, it remarkably increased from $0.48 \mathrm{~g} / \mathrm{cm}^{3}$ in the bottom ( $1^{\text {st }}$ internode) to 0.74 $\mathrm{g} / \mathrm{cm}^{3}$ in the upper parts $\left(20^{\text {th }}\right.$ internode $)$ for bamboo.
Figure 3 and 4 show modulus of rupture (MOR) and modulus of elasticity (MOE) of fresh, air-dried, and microwave-heated (MW) wood, rattan, and bamboo. MOR and MOE values of wood, rattan, and bamboo increased from fresh to air-dried and decreased by microwave-heated.

When compared at the range $\varrho$ from 0.48 to $0.55 \mathrm{~g} / \mathrm{cm}^{3}$, the average MOR of fresh wood, rattan, and bamboo samples were

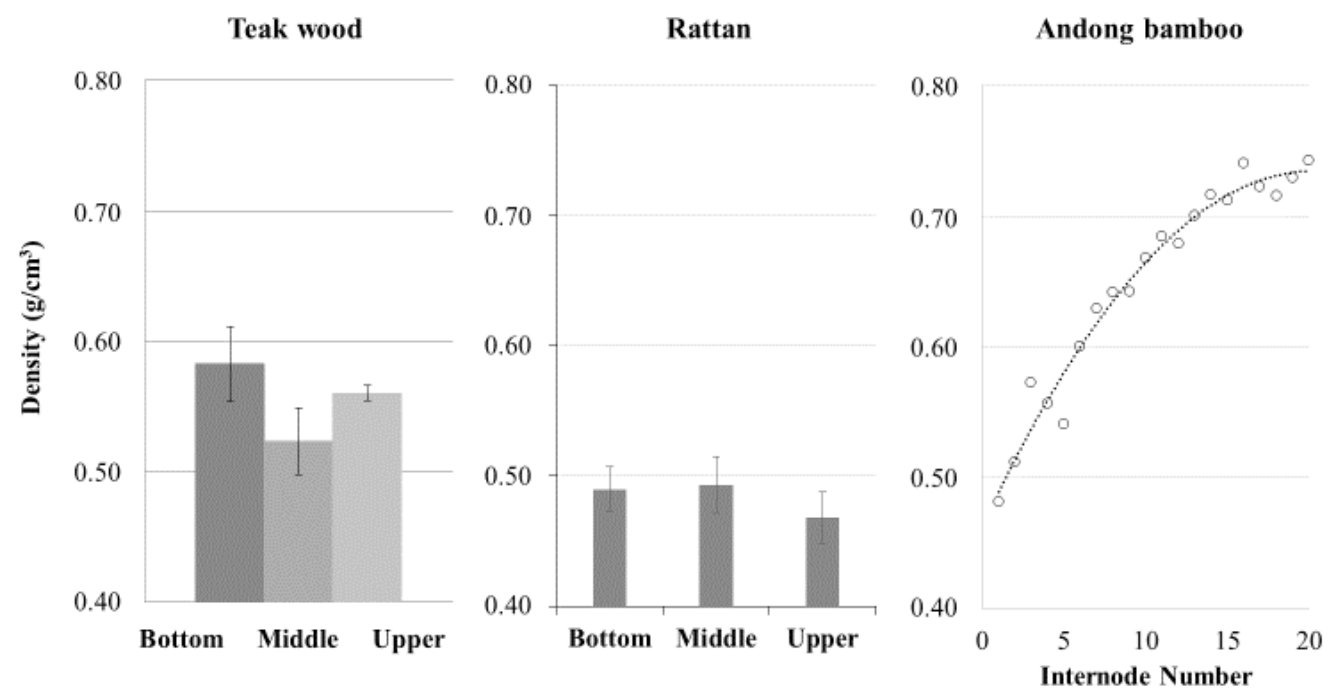

Figure 2. The density of air-dried wood, rattan, and bamboo
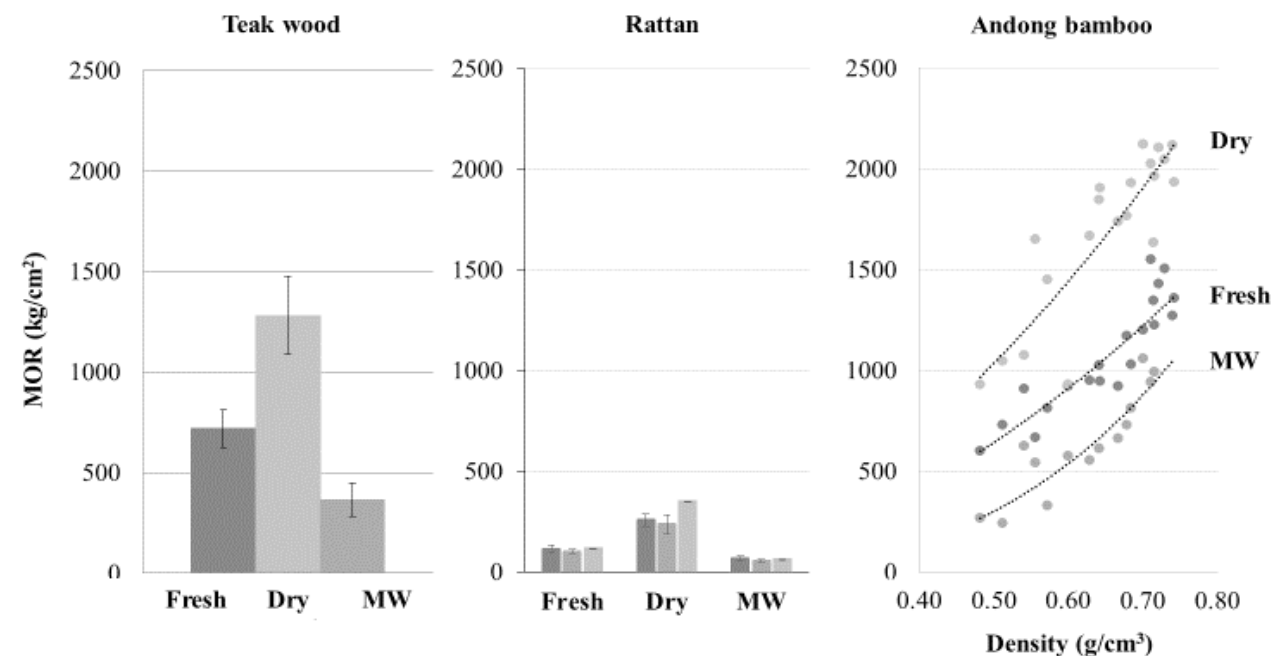

Figure 3. Modulus of rupture (MOR) of fresh, air-dried, and microwave-heated (MW) wood, rattan, and bamboo 

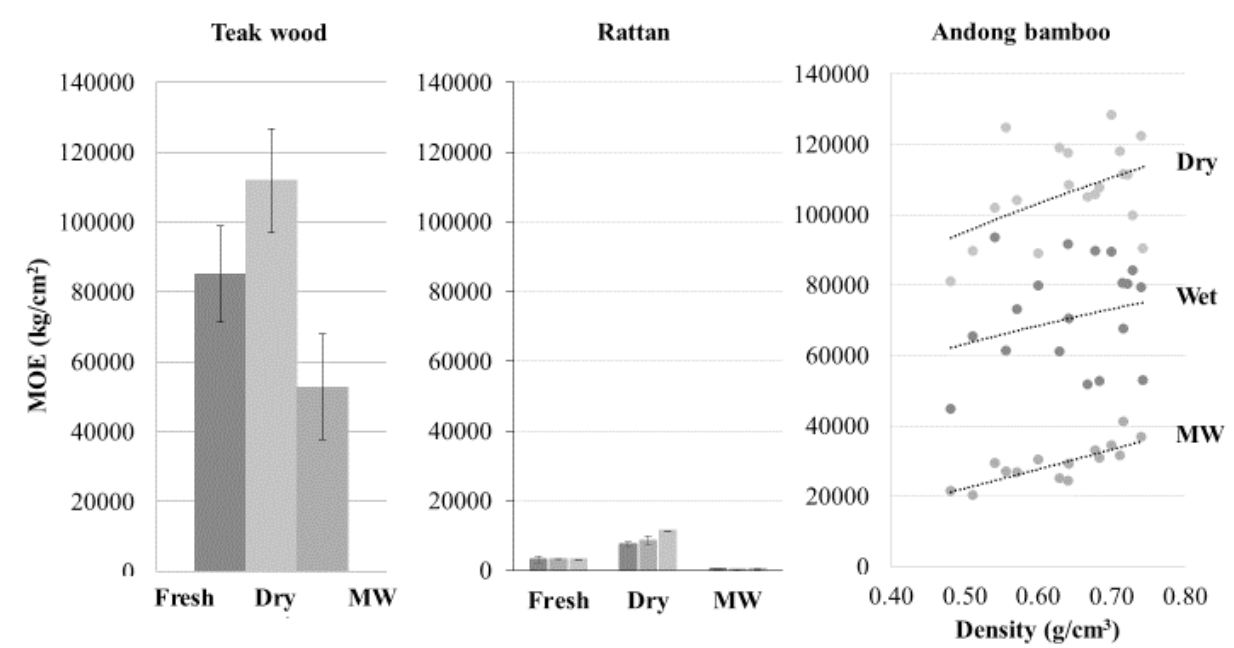

Figure 4. Modulus of elasticity (MOE) of fresh, air-dried, and microwave-heated (MW) wood, rattan, and bamboo

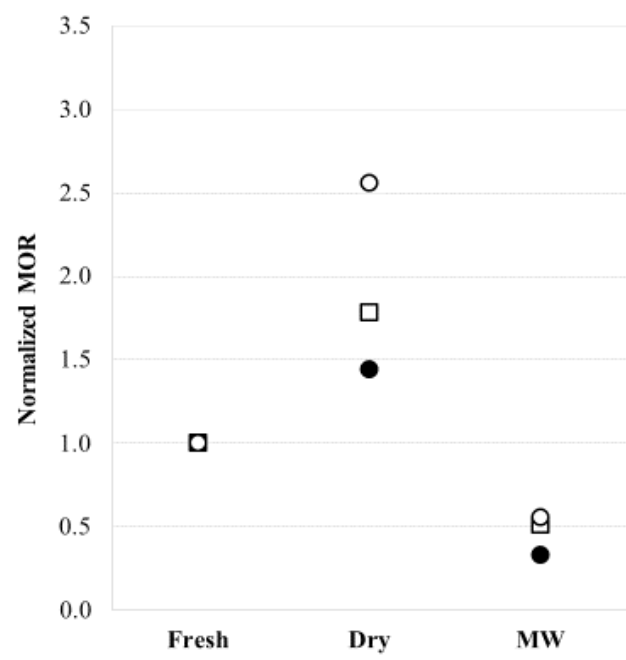

(a)

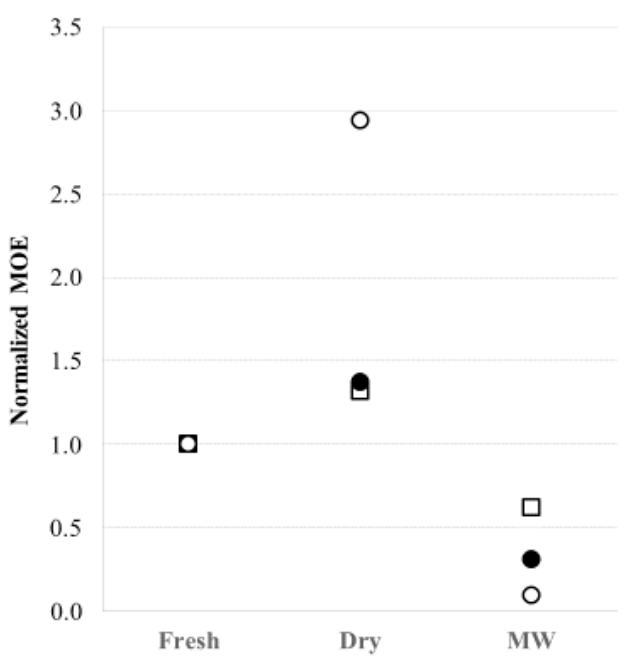

(b)

Figure 5. Normalized MOR (a) and MOE (b) values of fresh, air-dried, and microwave-heated (MW) wood ( $\square$ ), rattan (०), and bamboo

$717.59 \mathrm{~kg} / \mathrm{cm}^{2}, 113.65 \mathrm{~kg} / \mathrm{cm}^{2}$, and 599.07 $\mathrm{kg} / \mathrm{cm}^{2}$ respectively. Drastically the increase was determined for the average MOR in airdried rattan to $255.85 \mathrm{~kg} / \mathrm{cm}^{2}$ (increased by $125.12 \%$ ). However, the decreasing of MOR was almost the same when they were softened by microwave heating for one min.

An average MOE of fresh, air-dried, and softened wood were $85,183 \mathrm{~kg} / \mathrm{cm}^{2}, 111,948$ $\mathrm{kg} / \mathrm{cm}^{2}$ (increased $31.42 \%$ ), and $52,869 \mathrm{~kg} /$ $\mathrm{cm}^{2}$ (decreased $49.29 \%$ ), respectively. On the other hand, that for rattan were $3,092 \mathrm{~kg} / \mathrm{cm}^{2}$, $7,511 \mathrm{~kg} / \mathrm{cm}^{2}$ (increased 142.96\%), and 302 $\mathrm{kg} / \mathrm{cm}^{2}$ (decreased $90.25 \%$ ), respectively. As for bamboo were $44,685 \mathrm{~kg} / \mathrm{cm}^{2}, 80,867 \mathrm{~kg} /$ $\mathrm{cm}^{2}$ (increased 80.97\%), and 21,436 kg/ $\mathrm{cm}^{2}$ (decreased 52.03\%), respectively. Viscoelastic property of wood, rattan, and bamboo was more clearly compared by the normalized values of MOR and MOE in the same $Q$, as shown in Figure 5. 
Drastically increased was determined for the average normalized MOR in air-dried rattan, i.e. 2.5 fold. However, the decreasing of all the average normalized MOR were almost the same, i.e. 0.5 fold when they were softened by microwave-heated, although the average normalized MOR of bamboo were slightly lower than wood in air-dried and microwaveheated. Significant improvement has also appeared for the average normalized MOE in the air-dried rattan, i.e. 3 fold and decreased to almost zero by microwave-heated. On the other hand, the average normalized MOE of wood and bamboo were similar.

Figure 6 shows the anatomical structures of teak wood, calamus rattan, and andong bamboo. The wood has rays, almost uniform cell wall thickness, vessels, lumens, and pores. Rattan and bamboo consist of vascular bundles surrounded by ground parenchyma tissues that have very thin cell walls, phloem, and large cavity of metaxylem. Specifically, the anatomical structures of rattan are unique with the presence of protoxylem, as shown in Figure 7.

\section{B. Discussion}

Remarkable differences in fresh MC of wood, rattan, and bamboo were considered due to their anatomical structures. Fresh MC exists as free water that is contained as the liquid in the pores or vessels, and as bound water that is trapped within the cell walls. Fibre saturation point (FSP), when the fibres are completely saturated with bound water may be roughly $\pm 3 \% \mathrm{MC}$ depending on the wood species, but $30 \% \mathrm{MC}$ is the commonly-accepted average (Barkas, 1935). Mateo, Isabel, and María (2015) reported that the FSP of bamboo was 32\% \pm $3 \%$. Although it is not well known, the FSP of rattan is likely to be similar to wood and bamboo. From the above experiment results, as FSP represented bound water within the cell walls, the free water of wood, rattan, and bamboo were approximately around $70 \%$, more than $180 \%$, and 10 to $20 \%$, respectively.
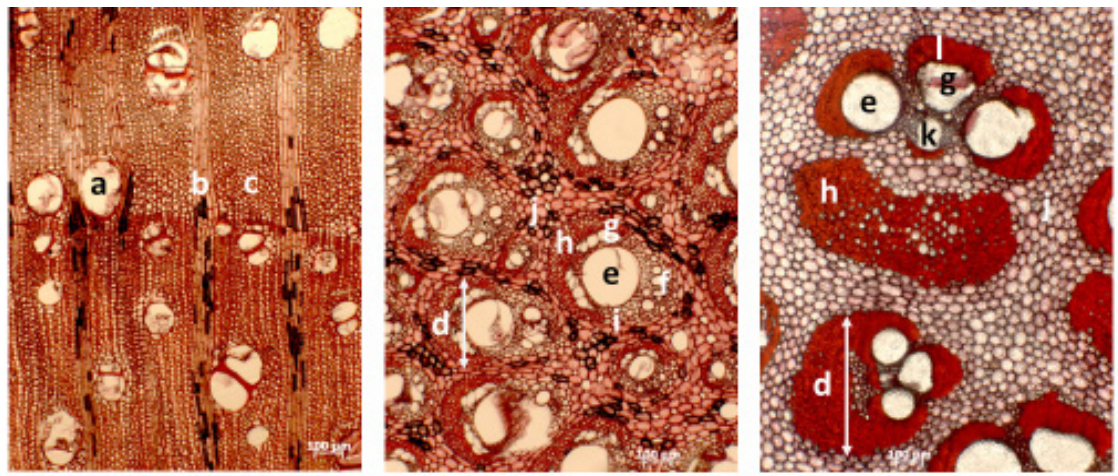

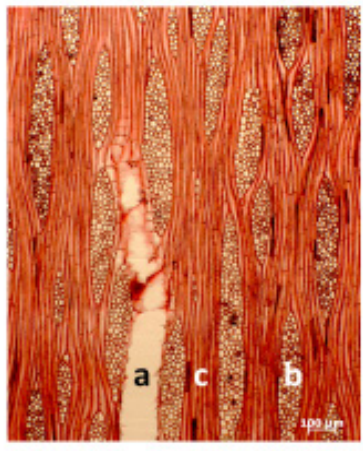

Teak Wood

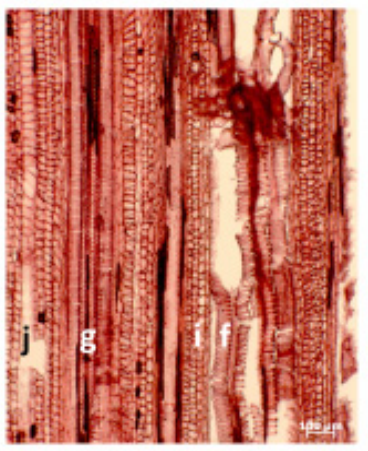

Calamus Rattan

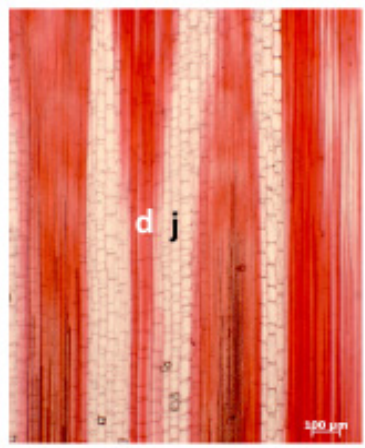

Andong Bamboo

Figure 6. Anatomical structures of the wood, rattan, and bamboo

Remarks: upper: cross-section; bottom: longitudinal direction; a: vessel, b: rays, c: fibres, d: vascular bundle, e: metaxylem, f: protoxylem, g: phloem; h: fibre sheats, i: axial parenchyma, j: ground parenchyma, k: intercellular canal; l: sclerenchyma 


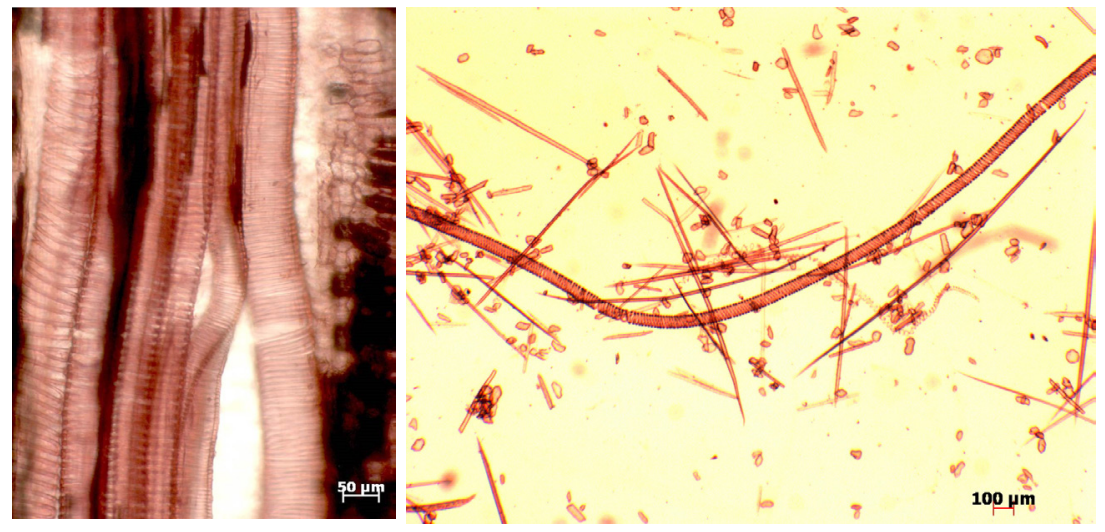

Figure 7. Protoxylem of rattan in the longitudinal direction

Nakajima et al. (2011) conducted the thermal softening behaviour of bamboo (Phyllostachys bambusoides) by submersing the specimens in a water bath under load and raising the temperature to $90^{\circ} \mathrm{C}$, then cooling the bath to $20^{\circ} \mathrm{C}$. They reported that the thermal softening behaviour of bamboo differs from that of wood (Japanese cypress - softwood), with a greater degree of residual deformation observed in the bamboo than in the wood. The high residual set of bamboo was associated with the thermalsoftening properties of lignin (Nakajima, Furuta, \& Ishimaru, 2008). Although they did not mention MC inside the specimens under loading condition, the result was in accordance with those previously stated that the softening temperature of wood saturated with water is between $80^{\circ} \mathrm{C}$ and $90^{\circ} \mathrm{C}$ (Becker \& Noack 1968) due to the glass transition temperatures of saturated modified lignin (Goring 1963). $\mathrm{MC}$ is an essential factor in thermal softening behaviour and hygro-plasticization occurring under dry conditions (bound water) or moist conditions (free water) of wood fibre-based materials (Salmen, 1982). Since the remarkably differences in fresh MC of wood, rattan, and bamboo in the same $\varrho$ was considered due to their anatomical structures, the difference in softening speed between wood, rattan and bamboo was caused by their MC.

The density of wood, rattan, and bamboo was also depended on their anatomical structures. Wood $\varrho$ is mainly determined by the relative thickness of the cell walls and the proportions of thick- and thin-walled cells present. The average $\varrho$ of 9 years-old fastgrowing teak wood was $0.55 \mathrm{~g} / \mathrm{cm}^{3}$, lower than that of 60 years-old conventional teak wood, i.e. $0.67 \mathrm{~g} / \mathrm{cm}^{3}$ (Adi et al., 2016). It was probably due to the proportion of juvenile wood towards the upper and inner parts of the stem (Bowyer, Shmulsky, \& Haygreen, 2003; Panshin, Zeeuw, \& Brown, 1980). Kadir (1997) reported that the $\varrho$ of Calamus scipionum ranged from 0.40 to $0.83 \mathrm{~g} / \mathrm{cm}^{3}$. The average $\varrho$ of rattan used in this experiment was within this range, i.e. $0.48 \mathrm{~g} / \mathrm{cm}^{3}$. The $\varrho$ of rattan was significantly correlated with height, the maturity of the stem and anatomical properties. Zhang, Shenxue, \& Yongyu (2002) reported that the basic $\varrho$ of bamboo was in the range of $0.40 \sim 0.80 \mathrm{~g} / \mathrm{cm}^{3}$. They argued that the basic $\varrho$ of bamboo mainly depended on the $\varrho$ of vascular bundles and their composition. As a rule, the $\varrho$ of bamboo stem increased from inner to the outer part, and from the lower to the upper part. Kabir, Bhattacharjee, and Sattar (1993); Patel, Maiwala, Gajera, Patel, and Magdallawala (2013; and Sattar, Kabir, and Bhattacharjee (1990) reported that the $\varrho$ of bamboo varied from 0.50 to 0.80 $\mathrm{g} / \mathrm{cm}^{3}$ depending on anatomical structures such as quantity and distribution of fibres around vascular bundles, with its maximum $\varrho$ usually obtained from 3 years old mature culms. 
MOR and MOE values of wood, rattan, and bamboo increased from fresh to air-dried and decreased by microwave-heated. Drastically increase was determined for the MOR and $\mathrm{MOE}$ in air-dried rattan. However, the lowering of MOR and MOE values were almost the same for wood, rattan, and bamboo when they were softened by microwave-heated. These results indicated that rattan was more easily bent, followed by bamboo and then wood. The MC of the lignocellulosic materials and microwave heating played an essential role in softening condition. Hydrothermal properties of chemical components significantly affected the changes of strength (MOR) and elastic properties (MOE).

Specifically, viscoelasticity is a molecular rearrangement. When a stress is applied to a viscoelastic material, part of the long polymer chain change positions. Polymers remain a solid material even when these parts of their chains are rearranging in order to accompany the stress. As this occurs, it creates back stress in the material. When the original stress is taken away, the accumulated back stresses will cause the polymer to return to its original form (McCrum, Buckley, \& Bucknall, 2003). The secondary bonds of a polymer constantly break and reform due to thermal motion. Application of stress favours some conformations over others, so the molecules of the polymer will gradually flow into the preferred conformations over time (Dotan, 2014). Because thermal motion is one factor contributing to the deformation of polymers, viscoelastic properties change with increasing or decreasing temperature. In other words, it takes less work to stretch a viscoelastic material an equal distance at a higher temperature than it does at a lower temperature. Both wood and cellulose materials are involved in such materials and the viscoelasticity which causes a variety of mechanical properties is closely related to thermal motions of a polymer chain of the material.

Semi-crystalline cellulose exhibits a broad transition region and thus displays a gradual softening at increasing moisture contents (Salmen, 1982). The crystallites restrict the motion of the tie molecules between the crystallites in the microfibrils and thus shift the transition in these regions to higher temperatures or higher moisture contents. For the amorphous carbohydrates, the plasticizing effect of water is estimated from a free volume. The cellulose microfibrils act as the reinforcements in a matrix of hemicelluloses. Therefore, the softening effect due to water immersion results from a softening of the disordered zones between the cellulose crystallites in the microfibril. Under these conditions, the fibre is best represented by a discontinuous reinforced system in which only the cellulose crystals act as reinforcing elements.

Under both dry and water-immersed conditions, apparent activation energy has been obtained for the glass transition of lignin. It is concluded that the changes in elastic properties of lignocellulosic materials with increasing moisture content are determined by a softening of the amorphous carbohydrates. The structural rigidity of wood fibres and fibre products is greatly influenced by the stiffness of their main polymeric components: cellulose, hemicelluloses and lignin (Zuraida et al., 2017). It is essential to take these variables, temperature, and water content into account when predicting the mechanical behaviour of cellulosic materials as they are responsible for the significant changes in the properties of the matrix in these structures.

Wood is composed mostly of hollow, elongated, spindle-shaped cells that are arranged parallel to each other along the trunk of a tree. The characteristics of these fibrous cells and their arrangement affect strength properties, appearance, and resistance to penetration by water and chemicals, and many other features. The stem of rattan consists of the vascular bundle with one metaxylem vessel, two phloem fields, and protoxylem. The parenchyma and fibres are other cells encompassing the vascular bundle. Metaxylem vessel is the largest cell in 
Calamus species, with an average diameter of 300 to $350 \mu \mathrm{m}$ (Weiner \& Liese, 1998). Any surrounding water could easily penetrate these voids. The tissues of bamboo stem include surface system (epidermis, subcutis, cortex), fundamental system (underlying tissues, pith rings, piths) and vascular system. The surface system is the bamboo skin, located in the outermost part, pith rings and pith located in innermost part. They form the outer and inner surface layers of the stem wall they are closely protecting the underlying tissues, and vascular system. Vascular bundles are distributed among the underlying tissues of the stem wall, and their density decreases from the outer side of the stem wall to the inner side (Zhang et al., 2002).

The deformation mechanism of bentwood cell walls is similar to that of compressed wood. However, the deformation of bentwood cell walls occurs mostly in the longitudinal direction (bending deformation), and that of compressed wood happens in the radial direction (compressive strain). The levels of bending deformation or bend-ability of the lignocellulosic materials depend on their cavities that could be deformed. In case of woods, they have rays and almost uniform cell wall thickness which strengthens their bending strength, even in softening condition. Therefore, the bendability of the woods depending on the portion of their vessels and lumens. Significant differences of the anatomical structure of rattans and bamboos to woods consist of vascular bundles surrounded by ground parenchyma tissues that have very thin cell walls. The metaxylem in vascular bundles of both bamboo and rattan strengthen their bending strength.

These anatomical observations indicated that rattan was more easily bent, followed by bamboo and then wood, due to the presence of protoxylem as a significant factor. Furthermore, the proportion of parenchyma cells and large cavity of metaxylem and phloem in rattan and bamboo were considered as parameters of their bend-ability. In addition, very thin parenchyma cell walls are more easily softened by microwave heating. Therefore, the differences in bending strength of wood, rattan, and bamboo were more likely due to differences in their anatomical structures rather than chemical components.

\section{CONCLUSION}

The softening behaviour and viscoelastic property of wood, rattan, and bamboo have been studied by static bending tests in fresh, air-dried, and softening conditions to determine MOR and MOE values. MOR and MOE values of wood, rattan, and bamboo increased from fresh to air-dried condition, and decreased by microwave heating. The drastic increase was observed for the MOR and MOE values in air-dried rattan and dropped to almost zero by microwave heating. These results indicated that rattan was more easily bent, followed by bamboo and then wood. The MC of the lignocellulosic materials and microwave heating played an essential role in softening condition. Hydrothermal properties of chemical components significantly affected the changes of strength (MOR) and elastic properties (MOE).

The proportion of parenchyma cells and large cavity of metaxylem and phloem in rattan and bamboo, and the dimension of protoxylem in rattan were considered as parameters of their bend-ability. In addition, very thin parenchyma cell walls are more easily softened by microwave heating. Therefore, the differences in bending strength of wood, rattan, and bamboo were more likely due to differences in their anatomical structures rather than chemical components.

\section{ACKNOWLEDGEMENT}

The authors would like to thank the Japan Society for the Promotion of Sciences (JSPS) which has funded under the FY 2019 of Invitational Fellowships for Research in Japan to conduct this research for a period of 6 months from July $1^{\text {st }}$ to December $27^{\text {th }}, 2019$ supervised by Prof. Junji Sugiyama as host researcher in the Laboratory of Biomass Morphogenesis and Information (LBMI), Research Institute 
for Sustainable Humanosphere (RISH), Kyoto University. Thanks are also dedicated to Prof. Junji Sugiyama who has reviewed this manuscript.

\section{REFERENCES}

Adi, D. S., Sudarmanto, Ismadi, Gopar, M., Darmawan, T., Amin, Y., ... Witjaksono. (2016). Evaluation of the wood quality of platinum teak wood. Teknologi Indonesia, 39(1), 36-44.

Agneta, M., Kuckurek, M., Pyiatte, J., \& EE, W. (1993). Kraft pulping. In A Compilation of Notes (pp. 6-7). TAPPI Press.

Asim, M., Saba, N., Jawaid, M., \& Nasir, M. (2018). Potential of natural fiber/biomass fillerreinforced polymer composites in aerospace applications. In M. Jawaid \& M. Thariq (Eds.), Sustainable in Composites for Aerospace Applications, A volume in Woodhead Publishing Series in Composites Science and Engineering Book. (pp. 253-268) doi://10.1016/C2016-001691-1.

Becker, H., \& Noack, D. (1968). Studies on the dynamic torsional viscoelasticity of wood. Wood Science Technology, 2(1), 213-230.

Barkas, W. (1935). Fibre saturation point of wood. Nature, 135, 545.

Bowyer, J. L., Shmulsky, R., \& Haygreen, J. G. (2003). Forest products and wood science: An introduction. (4 $4^{\text {th }}$ ed.). Iowa: Iowa State Press (Blackwell Publishing Company).

British Standard. (1957). British Standard 373-1957. Methods of testing small clear specimens of timber. BSI 07-1999.

Chen, H. (2015). Lignocellulose biorefinery feedstock engineering. In Lignocellulose Biorefinery Engineering, Lignocellulose Biorefinery Engineering Principles and Applications (pp. 3786). Elsevier Ltd. doi://10.1016/C2014-0$02702-5$

Dotan, A. (2014). Biobased thermosets. In H. Dodiuk \& S. Goodman (Eds.), Handbook of Thermoset Plastics Book ( $3^{\text {rd }}$ ed., pp. 577-622). doi://10.1016/C2011-0-09694-1.

Dwianto, W., Bahanawan, A., Darmawan, T., Akbar, F., Sufiandi, S., Adi, D., \& Damayanti, R. (2019). Lignocellulosic materials modification and engineering in relation to viscoelastic perspectives. In IOP Conf. Ser:: Earth Environ. Sci. 359 (p. 012013). doi://10.1088/17551315/359/1/012013.

Dwianto, W., Inoue, M., \& Norimoto, M. (1997). Fixation of compressive deformation of wood by heat treatment. Journal of the Japan Wood Research Society, 43(4), 303-309.

Dwianto, W., Kusumah, S. S., Darmawan, T., Amin, Y., Bahanawan, A., Pramasari, D. A., ... Damayanti, R. (2019). Anatomical observation and characterization on basic properties of agarwood (gaharu) as an Appendix II CITES. In IOP Conf. Series: Earth and Environmental Science 374 (p. 012062). doi://10.1088/17551315/374/1/011001.

Fazita, N., Jayaraman, K., Bhattacharyya, D., Haafiz, M., Saurabh, C., \& Hussin, M. (2016). Green composites made of bamboo fabric and poly(lactic) acid for packaging applications: A review. Materials, 9(6), 435.

Goring, D. A. L. (1963). Thermal softening of lignin, hemicellulose and cellulose. Pulp Paper Mag. Can. 64(12), T-517.

Hamdan, S., Dwianto, W., Morooka, T., \& Norimoto, M. (2000). Softening characteristics of wet wood under quasi-static loading. Holsforchung, 54, 557-560.

Hamdan, S., Dwianto, W., Morooka, T., \& Norimoto, M. (2004). Fitting parameters for softening of wet wood under quasi static loading. Holiforschung, 58, 134-137.

Kabir, M., Bhattacharjee, D., \& Sattar, M. (1993). Effect of age and height on strength properties of Dendrocalamus longispathus. Bamboo Information Centre India Bulletin, 3(1), 11-15.

Kadir, R. (1997). Stem properties of planted Calamus scipionum and Daemonorops angustifolia of different ages. Universiti Pertanian Malaysia.

Khalil, H., Bhat, I., Jawaid, M., Zaidon, A., Hermawan, D., \& Hadi, Y. (2012). Bamboo fiber reinforced biocomposites-A review. Materials and Design, 42, 353-368.

Li., L., Wang, Y., Wang, G., Cheng, H., \& Han, X. (2010). Evaluation of properties of natural bamboo fiber for application in summer textiles. Journal of Fiber Bioengineering and Informatics, 3(2), 94-99.

Li, Q., Song, J., Peng, S., Wang, J., Qu, G., Sederoff, R., \& Chiang, V. (2014). Plant biotechnology 
for lignocellulosic biofuel production. Plant Biotechnology Journal, 12(9), 1174-1192.

Lum, W., Lee, S., Ahmad, Z., Halip, J., \& Chin, K. (2019). Lignocellulosic nanomaterials for construction and building applications. In S. Thomas, Y. Grohens, \& Y. Pottathara (Eds.), Industrial Applications of Nanomaterials Micro and Nano Technologies (pp. 423-439). doi://10.1016/C2017-0-03283-4.

Mateo, G., Isabel, B., \& María, C. (2015). Determination of fiber saturation point of bamboo Guadua angustifolia Kunth. In $16^{\text {th }}$ NOCMAT. Winnipeg, Canada.

McCrum, N., Buckley, C., \& Bucknall, C. (2003). Principles of polymer engineering. Oxford Science Publication.

Meyers, M., \& Chawla, K. (2008). Mechanical behavior of materials. New York: Cambridge University Press.

Nakajima, M., Kojiro, K., Sugimoto, H., Miki, T., \& Kanayama, K. (2011). Studies on bamboo for sustainable and advanced utilization. Energy, 36(4), 2049-2054.

Nakajima, M., Furuta, Y., \& Ishimaru, Y. (2008). Thermal-softening properties and cooling set of water-saturated bamboo within proportional limit. Journal of Wood Science, 54(4), 278-284.

Olorunnisola, A., \& Adefisan, O. (2001). Trial production and testing of cement-bonded particleboard from rattan furniture water. Wood and Fiber Science, 34, 116-124.

Panshin, A. J., Zeeuw, C. de, \& Brown, H. P. (1980). Textbook of wood technology. Volume I: Structure, identification, uses, and properties of the commercial woods of the United States. New York: McGrawHill Book Company.
Patel, P., Maiwala, A., Gajera, V., Patel, J., \& Magdallawala, S. (2013). Performance evaluation of bamboo as reinforcement in design of construction element. Journal of Engineering and Science, 2(4), 55-63.

Salmen, L. (1982). Temperature and water induced softening behaviour of wood fiber based materials. Stockholm: Swedish Forest Products Research Laboratory Paper Technology Department.

Sattar, M., Kabir, M., \& Bhattacharjee, D. (1990). Effect of age and height position of muli (Melocanna baccifera) and borak (Bambusa balcooa) bamboos on their physical and mechanical properties. Journal of Forest Science, 19(1), 29-38.

Weiner, G., \& Liese, W. (1998). Anatomical structures and differences of rattan genera from Southeast Asia. Journal of Tropical Forest Science, 1, 122-132.

Zhang, Q., Shenxue, J., \& Yongyu, T. (2002). Industrial utilization on bamboo. Technical Report No. 26. The International Network for Bamboo and Rattan (INBAR), Beijing.

Zuraida, A., Maisarah, T., \& Maisarah, W. (2017). Mechanical, physical and thermal properties of rattan fibre-based binderless board. Journal of Tropical Forest Science, 29(4), 485-492. doi://10.26525/jtfs2017.29.4.485492. 